The Award of The Electrochemical Society (Takei Award)

\title{
Research and Development of Highly Active and Durable Electrocatalysts Based on Multilateral Analyses of Fuel Cell Reactions Hiroyuki UCHIDA*
}

Clean Energy Research Center, University of Yamanashi, Takeda 4, Kofu 400-8510, Japan

* Corresponding author: h-uchida@yamanashi.ac.jp

\begin{abstract}
In order to establish clear strategies for the design of electrocatalysts with high activity and high durability, fuel cell reactions have been analyzed by multilateral techniques. The use of monodisperse Pt or Pt-alloy nanocatalysts with uniform composition, which were highly dispersed over the whole surface of the carbon support by the nanocapsule method, contributed greatly in clarifying the effects of various properties (particle size, composition, and surface structure, etc.) towards the activity and durability for the anode and cathode in polymer electrolyte fuel cells (PEFCs). New catalyst layers have been developed in order to make the electrocatalysts work effectively specifically under low humidity. Several important concepts have been demonstrated for developing high-performance oxygen and hydrogen electrodes with high durability for a reversible solid oxide cell (R-SOC), which is expected to be a reciprocal direct energy converter between hydrogen and electricity with high efficiency.
\end{abstract}

(c) The Electrochemical Society of Japan, All rights reserved.

Keywords : Polymer Electrolyte Fuel Cell, Electrocatalyst, Pt Alloy, Solid Oxide Fuel Cell

\section{Introduction}

Fuel cells convert chemical energy into electricity via electrochemical reactions with high efficiency and minimal emission of pollutants. Polymer electrolyte fuel cells (PEFCs) have been developed specifically for applications such as fuel cell vehicles (FCVs) and residential co-generation systems. Solid oxide fuel cells (SOFCs), which have been developed mainly for highly efficient stationary power generation, can be operated in the reverse mode [solid oxide electrolysis cell (SOEC)] to generate hydrogen via water vapor electrolysis, i.e., a reversible solid oxide cell (R-SOC).

In order to promote their large-scale commercialization toward a hydrogen-based society, it is crucial to reduce the system cost while maintaining high performance and durability. A single cell consists of an electrolyte (polymer electrolyte membrane, PEM, such as Nafion in the PEFC or a solid oxide electrolyte such as yttriastabilized zirconia, YSZ, in the SOFC) sandwiched between two electrodes or electrocatalyst layers (usually denoted as catalyst layers, CLs). One of the most important subjects to be pursued is the further improvement of the activity and durability of the electrocatalysts, because the overpotential predominantly reduces the efficiency of fuel cells. However, as described below, clear strategies for the design of the electrocatalyst itself and its effective utilization in the CL have not been established yet.

We have engaged in the research and development (R \& D) of electrocatalysts with respect to fundamentals and applications, intending to demonstrate new design concepts for realizing high activity together with high durability. ${ }^{1-4}$ For PEFC anode and cathode catalysts, the activity and its degradation have been analyzed by multilateral techniques such as X-ray photoelectron spectroscopy combined with an electrochemical cell (EC-XPS), ${ }^{2,5-8}$ in situ Fourier-transform infrared spectroscopy (FTIR), ${ }^{9-22}$ electrochemical quartz crystal microbalance (EQCM), ${ }^{23-26}$ in situ scanning tunneling microscopy (STM), ${ }^{27-31}$ in addition to conventional electrochemical measurements such as rotating disk electrode (RDE), ${ }^{32-34}$ channel flow electrode (CFE), ${ }^{21,35,36}$ and channel flow double electrode
(CFDE) methods. ${ }^{37-42}$ Based on these results, new practical catalysts have been synthesized. ${ }^{43-55}$ New catalyst layers or membraneelectrode-assemblies (MEAs) have been developed in order to make the electrocatalysts work effectively under widely varying operating conditions of relative humidity $(\mathrm{RH})$ and temperature. ${ }^{56-72}$ Changes in the distribution of the specific resistance in the PEM and oxygen partial pressure at the CL/PEM interface during operation, ${ }^{73-75}$ as well as the degradation mechanism of the MEAs, ${ }^{59,63,64,76,77}$ were also analyzed to feedback information to the syntheses of PEMs and catalysts. For the R-SOC, high-performance, high-durability electrodes with novel architecture have been developed, while clarifying clues for the further improvement of activity and durability. ${ }^{78-100}$

In the present comprehensive paper, these recent research works are reviewed.

\section{PEFC Cathode Catalysts}

Costly Pt and its alloys have been used as the cathode catalyst, having appreciable activity and durability under strongly acidic conditions (in contact with the polymer electrolyte binder) at low operating temperatures $<100^{\circ} \mathrm{C}$. A sluggish oxygen reduction reaction (ORR) causes a large overpotential, even at the Pt cathode.

$$
\mathrm{O}_{2}+4 \mathrm{H}^{+}+4 \mathrm{e}^{-} \rightarrow 2 \mathrm{H}_{2} \mathrm{O}
$$

Hence, worldwide R \& D has been focused on reducing the mass of Pt used in the cathode, for reasons of cost and supply limitation, while maintaining the durability.

The mass activity $M A$ of Pt-based catalysts is the product of the area-specific activity $j_{\mathrm{s}}$ and the electrochemically active surface area $E C A$ :

$$
M A\left(\mathrm{Ag}_{\mathrm{Pt}}{ }^{-1}\right)=j_{\mathrm{s}}\left(\mathrm{A} \mathrm{m}_{\mathrm{Pt}}{ }^{-2}\right) \times E C A\left(\mathrm{~m}^{2} \mathrm{~g}_{\mathrm{Pt}}{ }^{-1}\right)
$$

To increase the value of $j_{\mathrm{s}}$ (current density per ECA), Pt alloys (Pt-Fe, Pt-Co, and Pt-Ni) have been examined. ${ }^{101-103}$ Because the $E C A$ value is inversely proportional to the diameter for spherical catalyst particles, it is an effective strategy for enlarging $E C A$ to 
disperse Pt or Pt-alloy nanoparticles (NPs) on high-surface-area supports such as carbon black (CB). However, for developing cathode catalysts having both high $M A$ for the ORR and high durability, there has been long-standing controversy surrounding essential issues such as the types of alloys, the chemical composition, their optimum particle size, as well as the mechanism of enhancement of $j_{\mathrm{s}}$ at Pt-alloys. In the next two Sections, such important factors are demonstrated. All of the potentials in Chapters 2 and 3 will be referred to the reversible hydrogen electrode (RHE).

\subsection{Effect of particle size and uniform dispersion on the activity and durability of $\mathrm{Pt}$ nanoparticles supported on carbon}

The first issue is the particle-size effect of Pt NPs on $j_{\mathrm{s}}$. It has been reported that the $j_{\mathrm{s}}$ values for the ORR decrease with decreasing average diameter $d_{\mathrm{Pt}} \cdot{ }^{104-106}$ For example, Gasteiger et al. have reported a strong particle-size effect on the kineticallycontrolled $j_{\mathrm{s}}$ (denoted as $j_{\mathrm{k}}$ ) on commercial c-Pt/CB catalysts for $d_{\mathrm{Pt}}$ ranging from $2 \mathrm{~nm}$ to bulk-Pt in $\mathrm{O}_{2}$-saturated $0.1 \mathrm{M} \mathrm{HClO}_{4}$ by the use of the RDE technique only at $60^{\circ} \mathrm{C}$, but the dependence of $j_{\mathrm{k}}$ on $d_{\mathrm{Pt}}$ was fairly small between 3 and $8 \mathrm{~nm}$. ${ }^{106}$ They evaluated $j_{\mathrm{k}}$ at $0.9 \mathrm{~V}$ from the hydrodynamic voltammograms measured with a sweep rate of $20 \mathrm{mV} \mathrm{s}^{-1}$ to avoid electrode contamination by impurities in the electrolyte solution, although they recognized that the coverage of oxygen species $\left(\mathrm{O}_{\mathrm{ad}}\right.$ and $\left.\mathrm{OH}_{\mathrm{ad}}\right)$ cannot stabilize at such a high sweep rate, showing a large hysteresis between the positive-going and negative-going scans.

Then, in order to evaluate the steady-state $j_{\mathrm{k}}$ and $\mathrm{H}_{2} \mathrm{O}_{2}$ yield produced via the two-electron reduction of $\mathrm{O}_{2}, P\left(\mathrm{H}_{2} \mathrm{O}_{2}\right)$, of various $\mathrm{Pt} / \mathrm{CB}$ catalysts $\left(d_{\mathrm{Pt}}=1.6,2.6\right.$, and $\left.4.8 \mathrm{~nm}\right)$ and bulk-Pt in the practical temperature range of PEFCs $\left(30\right.$ to $\left.110^{\circ} \mathrm{C}\right)$, we measured hydrodynamic voltammograms by using a CFDE cell at a slow sweep rate $\left(0.5 \mathrm{mV} \mathrm{s}^{-1}\right) .^{40}$ The use of $0.1 \mathrm{M} \mathrm{HClO}_{4}$ electrolyte solution, which was purified in advance by a conventional preelectrolysis method, ${ }^{107,108}$ allowed us to obtain steady-state ORR voltammograms with neither hysteresis nor interference by impurities at such a low sweep rate. Moreover, $\mathrm{Pt} / \mathrm{CB}$ was uniformly dispersed on a gold substrate electrode at a constant loading of $\mathrm{CB}$ support, $5.5 \mu \mathrm{g} \mathrm{cm}^{-2}$ (corresponding to approximately one monolayer of CB particles) and coated with a thin Nafion film $(0.1 \mu \mathrm{m})$, in order to minimize the $\mathrm{O}_{2}$ diffusion resistance within the thin catalyst layer. ${ }^{39}$ We have demonstrated that the ORR rate constant $\left(k_{\text {app }}\right.$, per unit ECA), its activation energy, and $P\left(\mathrm{H}_{2} \mathrm{O}_{2}\right)$ in $\mathrm{O}_{2}$-saturated $0.1 \mathrm{M}$ $\mathrm{HClO}_{4}$ were all independent of $d_{\mathrm{Pt}}$ from $\mathrm{Pt}_{1.6 \mathrm{~nm}} / \mathrm{CB}$ to bulk-Pt at 30 to $50^{\circ} \mathrm{C}$, as well as from $\mathrm{Pt}_{2.6 \mathrm{~nm}} / \mathrm{CB}$ to bulk-Pt up to $110^{\circ} \mathrm{C}$. $^{40}$

It was also found that the smallest $\left(\mathrm{Pt}_{1.6 \mathrm{~mm}}\right)$ particles agglomerated at higher temperatures $\left(\geq 60^{\circ} \mathrm{C}\right)$. This result led our research to the second important issue regarding the Pt particle-size effect on the durability. A common view is that, the smaller the Pt particles are, the less durable they are with respect to load-cycling. ${ }^{109,110}$ It has been also noted that pristine $\mathrm{Pt} / \mathrm{CB}$ catalysts prepared by conventional methods usually showed a broad distribution of sizes (standard deviation $\sigma_{\mathrm{d}} \geq 20 \%$ ). Considering the Ostwald ripening mechanism, ${ }^{111}$ in which smaller particles predominantly dissolve and the resulting $\mathrm{Pt}^{\mathrm{n}+}$ ions redeposit onto larger particles, it is necessary to examine the particle-size effect on the durability toward load-cycling by the use of $\mathrm{Pt} / \mathrm{CB}$ catalysts with uniform Pt size.

Therefore, with an identical heat-treatment by the nanocapsule method, ${ }^{43,45}$ three kinds of catalysts $\left(\mathrm{n}-\mathrm{Pt} / \mathrm{CB}, d_{\mathrm{Pt}}=2,3\right.$, and $4 \mathrm{~nm}$, specific surface area of $\mathrm{CB}=800 \mathrm{~m}^{2} / \mathrm{g}$ ) were prepared with a very narrow $\sigma_{\mathrm{d}}(\mathrm{ca} .10 \%){ }^{42}$ Figure 1 shows changes in the $M A_{\mathrm{k}}$ and $j_{\mathrm{k}}$ at $0.85 \mathrm{~V}$ and $65^{\circ} \mathrm{C}$ on the $\mathrm{n}-\mathrm{Pt} / \mathrm{CB}$ and a standard c- $\mathrm{Pt}_{2 \mathrm{~nm}} / \mathrm{CB}$ $\left(\sigma_{\mathrm{d}}=20 \%\right)$ in $0.1 \mathrm{M} \mathrm{HClO}_{4}$ as a function of the number of potentialstep cycles $N$ during an accelerated durability test (ADT), according to a protocol recommended by the Fuel Cell Commercialization Conference of Japan (FCCJ). ${ }^{112}$ At $N=0$ (the beginning of testing,

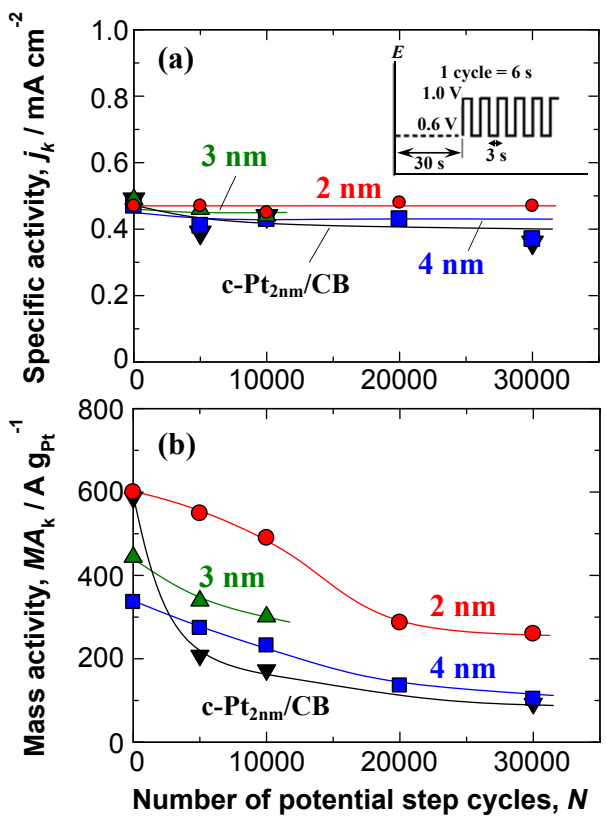

Figure 1. (Color online) Changes in (a) kinetically-controlled area-specific activity, $j_{\mathrm{k}}$, and (b) kinetically-controlled mass activity, $M A_{\mathrm{k}}$ at Nafion-coated $\mathrm{n}-\mathrm{Pt}_{2 \mathrm{~nm}} / \mathrm{CB}(\mathrm{O}), \mathrm{n}-\mathrm{Pt}_{3 \mathrm{~nm}} / \mathrm{CB}(\Delta), \mathrm{n}-\mathrm{Pt}_{4 \mathrm{~nm}} / \mathrm{CB}$

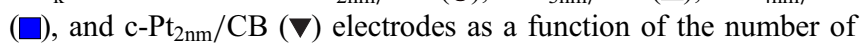
potential step cycles, $N$. The values of $j_{\mathrm{k}}$ and $M A_{\mathrm{k}}$ were evaluated at $0.85 \mathrm{~V}$ vs. RHE in $\mathrm{O}_{2}$-saturated $0.1 \mathrm{M} \mathrm{HClO}_{4}$ at $65^{\circ} \mathrm{C}$. The ADT was performed in $\mathrm{N}_{2}$-saturated $0.1 \mathrm{M} \mathrm{HClO}_{4}$ at $65^{\circ} \mathrm{C}$ according to the FCCJ protocol. ${ }^{112}$ Reproduced from Ref. 42 with permission of Elsevier Ltd.

BOT), all catalysts exhibited the identical value of $j_{\mathrm{k}}$, and the $M A_{\mathrm{k}}$ was proportional to the $E C A$ (inversely proportional to $d_{\mathrm{Pt}}$ ). With increasing $N$, the $M A_{\mathrm{k}}$ values of all catalysts decreased due to the reduction of the $E C A$, as a result of particle growth, but the $j_{\mathrm{k}}$ values were nearly unchanged, irrespective of such particle growth. After 30,000 cycles, at which each $M A_{\mathrm{k}}$ (or $E C A$ ) had reached a stable value (end of testing, EOT), the smallest Pt catalyst $\left(\mathrm{n}-\mathrm{Pt}_{2 \mathrm{~nm}} / \mathrm{CB}\right)$ still maintained the highest $M A_{\mathrm{k}}$, which was a factor of approximately two higher than those of $n-\mathrm{Pt}_{4 \mathrm{~nm}} / \mathrm{CB}$ and c- $-\mathrm{Pt}_{2 \mathrm{~nm}} / \mathrm{CB}$. Thus, contrary to the common view stated above, Pt NPs as small as $2 \mathrm{~nm}$ were found to be quite durable, maintaining high performance from the BOT to EOT, as long as they were uniform in size $\left(\sigma_{d} \leq 10 \%\right)$ and highly dispersed over the whole surface of the carbon support.

In addition to load-cycling, startup/shutdown-cycling in FCVs also causes severe degradation of $\mathrm{Pt} / \mathrm{CB}$ cathode catalysts due to carbon corrosion at high potentials $(1.3$ to $1.5 \mathrm{~V}) .{ }^{113}$ The carbon corrosion was found to be mitigated significantly by the use of Pt NPs with uniform size and uniform dispersion on a corrosionresistant graphitized CB (GCB) support, ${ }^{46-48}$ to which our nanocapsule method has contributed greatly.

We have been extending these concepts to alloy nanocatalysts, as discussed in the next Sections.

\subsection{Mechanism of enhanced ORR activities at Pt skin layers formed on Pt-alloys and design of stabilized Pt skin catalysts}

By the use of polycrystalline thin films Pt-Fe, Pt-Co, and Pt-Ni alloy RDEs, we clarified the composition-dependence of $j_{\mathrm{k}}$ values for the ORR in $0.1 \mathrm{M} \mathrm{HClO}_{4}$ solution at room temperature. ${ }^{102}$ Based on EQCM, STM, and XPS analyses, we first clarified the mechanism for the enhancement of the $j_{\mathrm{k}} \cdot{ }^{1,3,4}$ It has been clearly demonstrated that nonprecious metal elements in these alloys are dissolved in acidic solution, followed by the spontaneous formation of a Pt skin layer, and the electronic state of the Pt skin is modified by the 


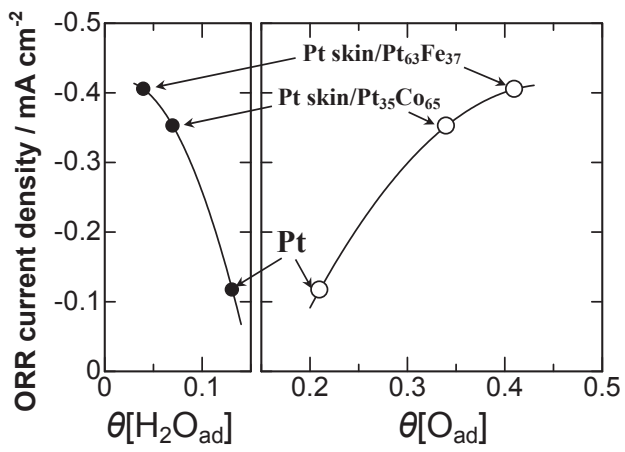

Figure 2. Relation between the ORR current density and coverage of $\mathrm{O}_{\mathrm{ad}}, \theta\left[\mathrm{O}_{\mathrm{ad}}\right]$ and $\mathrm{H}_{2} \mathrm{O}_{\mathrm{ad}}, \theta\left[\mathrm{O}_{\mathrm{ad}}\right]$ for pure Pt, Pt skin $/ \mathrm{Pt}_{33} \mathrm{Co}_{65}$ and $\mathrm{Pt}$ skin $/ \mathrm{Pt}_{63} \mathrm{Fe}_{37}$ at $0.90 \mathrm{~V}$ vs. RHE in $\mathrm{O}_{2}$-saturated $0.1 \mathrm{M} \mathrm{HF}$ measured by EC-XPS. 2,6

underlying alloy. The value of activation energy $\varepsilon_{\mathrm{a}}$ for the $k_{\text {app }}$ on $\mathrm{Pt}$ skin/Pt alloys at temperatures $\leq 60^{\circ} \mathrm{C}$ was found to be identical with that of pure $\mathrm{Pt}^{38}{ }^{38}$ indicating that the enhanced ORR activities on $\mathrm{Pt}$ skin/Pt alloys can be ascribed to an increased pre-exponential factor in the Arrhenius equation. Such a result is completely inconsistent with the claim, based on density functional theory (DFT) calculations, that decreases in the $\mathrm{O}_{\mathrm{ad}}$ and $\mathrm{OH}_{\mathrm{ad}}$ bonding energies in the ORR on the Pt alloys result in a decrease in the $\varepsilon_{\mathrm{a}}{ }^{114}$

By EC-XPS technique, we have, for the first time, quantitatively identified oxygen-containing species $\left(\mathrm{O}_{\mathrm{ad}}, \mathrm{OH}_{\mathrm{ad}}\right.$, and $\left.\mathrm{H}_{2} \mathrm{O}_{\mathrm{ad}}\right)$ on $\mathrm{Pt}$ skin/Pt alloys in $\mathrm{N}_{2-}$ and $\mathrm{O}_{2}$-saturated $0.1 \mathrm{M} \mathrm{HF}$ solution. ${ }^{2-4,6}$ The values of coverage of $\mathrm{OH}_{\mathrm{ad}}, \theta\left[\mathrm{OH}_{\mathrm{ad}}\right]$, on Pt-skin/Pt alloys and purePt were at nearly the same level. This is completely inconsistent with the common view that the enhancement in the ORR activity on Pt alloys is due to a mitigation of blocking or "poisoning" of the surface by decreasing $\theta\left[\mathrm{OH}_{\mathrm{ad}}\right]$ or coverage of $\mathrm{O}_{\mathrm{ad}}, \theta\left[\mathrm{O}_{\mathrm{ad}}\right]{ }^{114,115}$ As shown in Fig. 2, the ORR current density at $0.9 \mathrm{~V}$ increased with increasing $\theta\left[\mathrm{O}_{\mathrm{ad}}\right]$, measured after emersion of the electrode during the ORR, for pure Pt, Pt skin/Pt-Co, and Pt skin/Pt-Fe. A low $\theta\left[\mathrm{H}_{2} \mathrm{O}_{\mathrm{ad}}\right]$ at $\mathrm{Pt}$ skin/Pt alloys suggests an increase in the number of sites available for the dissociative adsorption of $\mathrm{O}_{2}$ at the Pt skin.

Such EC-XPS results provided a great impact, but several researchers have claimed that the emersion of the electrodes into ultrahigh vacuum is not suitable for the analysis. However, our recent series of measurements by EQCM and RDE, with a careful consideration on the specific adsorption of $\mathrm{ClO}_{4}{ }^{-}$anions, have demonstrated strong evidence that the higher ORR activity on the $\mathrm{Pt}_{3} \mathrm{Co}$ alloy is correlated with higher coverage of oxygen species. ${ }^{25,26}$

\subsection{Design of stabilized Pt skin/Pt alloy catalysts}

By the use of the nanocapsule method, monodisperse $\mathrm{Pt}_{\mathrm{X}} \mathrm{Co}$ (atomic ratio $\mathrm{X}=1,2$, and 3) alloy NPs supported on $\mathrm{CB}$ (n-Pt ${ }_{\mathrm{X}} \mathrm{Co}$ / $\mathrm{CB})$ were prepared with well-controlled particle size and alloy composition. ${ }^{44}$ The value of $k_{\text {app }}$ for the ORR at X $=3(d=1.9 \mathrm{~nm})$ at 30 to $70^{\circ} \mathrm{C}$ was found to be comparable to that for a bulk- $\mathrm{Pt}_{68} \mathrm{Co}_{32}$ (thin film) electrode, ${ }^{38}$ which was higher by a factor of 2.2 than that for a c-Pt/CB $\left(d_{\mathrm{Pt}}=2.6 \mathrm{~nm}\right)$, corresponding to an increase in $M A_{\mathrm{k}}$ by a factor of 3.3. However, the durability of both $\mathrm{n}-\mathrm{Pt}_{3} \mathrm{Co} / \mathrm{C}$ and bulk$\mathrm{Pt}_{68} \mathrm{Co}_{32}$ was insufficient, since the dealloying of $\mathrm{Co}$ was not fully suppressed at high temperatures $\geq 80^{\circ} \mathrm{C}$, and the $k_{\text {app }}$ values finally settled to a value comparable to those of c-Pt/CB or bulk-Pt. ${ }^{44}$

We consider that an essential point is the well-controlled formation of a stable, uniform, thin Pt skin layer, which protects the underlying alloy from corrosion and maintains the modified electronic structure. Very recently, we have successfully prepared monodisperse PtCo alloy NPs, having approximately two atomic layers of stabilized Pt skin, dispersed uniformly on graphitized carbon black $(\mathrm{GCB})$ or high-surface-area carbon black $\left(\mathrm{Pt}_{x \mathrm{AL}}-\mathrm{PtCo} /\right.$
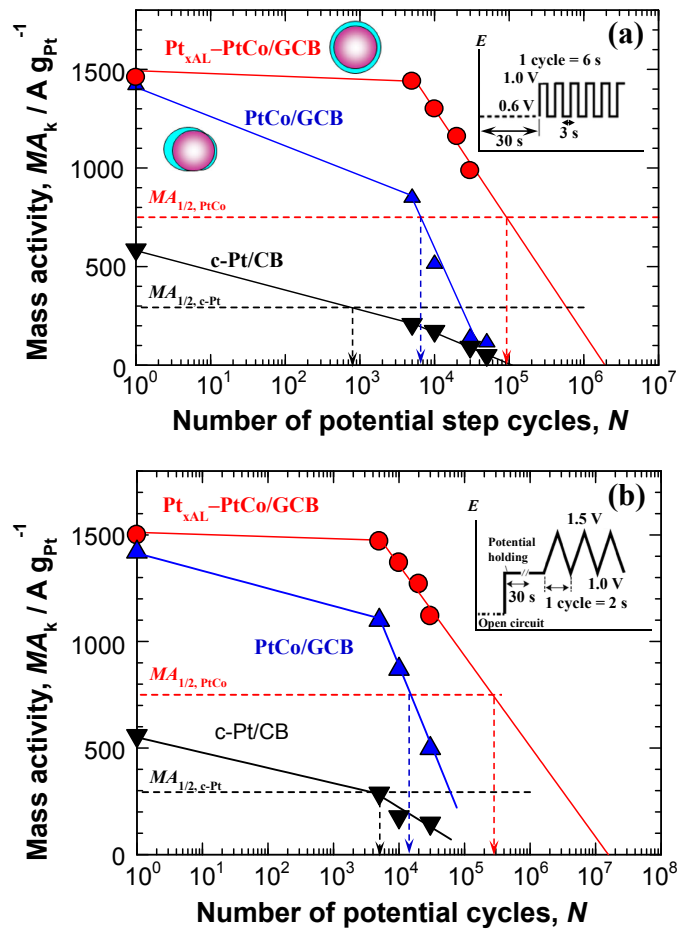

Figure 3. (Color online) Changes in kinetically-controlled mass activity, $M A_{\mathrm{k}}$ at Nafion-coated $\mathrm{Pt}_{x \mathrm{AL}}-\mathrm{PtCo} / \mathrm{GCB}(\mathrm{O}), \mathrm{PtCo} / \mathrm{GCB}$ $(\boldsymbol{\Delta})$, and $\mathrm{c}-\mathrm{Pt} / \mathrm{CB}(\boldsymbol{\nabla})$ electrodes as a function of (a) the number of potential step cycles, $N$, simulating load-cycles and (b) the number of potential cycles, $N$, simulating startup/shutdown-cycles. The values $M A_{\mathrm{k}}$ were evaluated at $0.85 \mathrm{~V}$ vs. RHE in $\mathrm{O}_{2}$-saturated $0.1 \mathrm{M}$ $\mathrm{HClO}_{4}$ at $65^{\circ} \mathrm{C}$. Replotted into $\log N$-scale from Ref. 52 .

GCB or $\mathrm{Pt}_{x \mathrm{AL}}-\mathrm{PtCo} / \mathrm{C}, 1<x \leq 2$ by more recent analysis). ${ }^{52,53}$ Figure 3 shows the variations in $M A_{\mathrm{k}}$ at $0.85 \mathrm{~V}$ on $\mathrm{Pt}_{x \mathrm{AL}}-\mathrm{PtCo} / \mathrm{GCB}$ as a function of $\log N$ in potential changes at $65^{\circ} \mathrm{C}$, simulating loadcycles and startup/shutdown-cycles of FCVs. The initial $M A_{\mathrm{k}}$ for both $\mathrm{Pt}_{x \mathrm{AL}}-\mathrm{PtCo} / \mathrm{GCB}$ and $\mathrm{PtCo} / \mathrm{GCB}$ was a factor of ca. 2.5 higher than that for c-Pt/CB. As a measure of the durability, we defined $N_{1 / 2}$, i.e., the value of $N$ elapsed for the reduction of $M A_{\mathrm{k}}$ to $1 / 2$ of the initial value for each catalyst $\left(M A_{1 / 2, \mathrm{c}-\mathrm{Pt}}\right.$ and $\left.M A_{1 / 2, \mathrm{PtCo}}\right)$. Assuming a Tafel slope of $-70 \mathrm{mV}$ for the ORR, ${ }^{38}$ a halved $M A$ results in a voltage loss of $21 \mathrm{mV}(=70 \times \log 2,2.4 \%$-loss from $0.85 \mathrm{~V})$ for the same current output. The $M A_{\mathrm{k}}$ value for $\mathrm{PtCo} / \mathrm{GCB}$ decreased steeply and approached that for c-Pt/CB after 30,000 cycles, mainly due to the dealloying of $\mathrm{Co}$, since the $j_{\mathrm{k}}$ became identical with that of c-Pt/CB. In contrast, the degradation of $M A_{\mathrm{k}}$ for $\mathrm{Pt}_{x \mathrm{AL}}-\mathrm{PtCo} / \mathrm{GCB}$ was suppressed considerably: the $N_{1 / 2}$ values were 14 and 128 times longer, respectively, than those for $\mathrm{PtCo} / \mathrm{GCB}$ and $\mathrm{c}-\mathrm{Pt} / \mathrm{CB}$. It is noteworthy that the $j_{\mathrm{k}}$ value on $\mathrm{Pt}_{x \mathrm{AL}}-\mathrm{PtCo} / \mathrm{GCB}$ was maintained at a constant value to 30,000 cycles, suggesting that the stabilized Pt skin layers protected the PtCo core perfectly from the dissolution of $\mathrm{Co}^{52}$ A very high durability of $\mathrm{Pt}_{x \mathrm{AL}}-\mathrm{PtCo} / \mathrm{GCB}$ versus high potentials (simulating startup/shutdown-cycles of FCVs) is clearly seen in Fig. 3(b). Carbon-supported $\mathrm{Pt}_{x \mathrm{AL}}-\mathrm{Pt}-\mathrm{M}(\mathrm{M}=\mathrm{Fe}, \mathrm{Co}$, and $\mathrm{Ni})$ also exhibited superior performances both in the $M A_{\mathrm{k}}$ and the durability. ${ }^{53}$ A collaborative effort with a catalyst company is under way to establish an industrial preparation method of these new catalysts.

\section{Anode Catalysts for Residential PEFCs and Direct Oxidation Fuel Cells}

The overpotential for the hydrogen oxidation reaction (HOR) is very small at $\mathrm{Pt} / \mathrm{CB}$ anode catalysts operated with pure $\mathrm{H}_{2}$, as in FCVs. ${ }^{65}$ However, for residential PEFCs, the HOR at Pt/CB is severely poisoned by $\mathrm{CO}$, even at low concentrations, in the 
reformate, which is produced by the reforming of fuels $\left(\mathrm{CH}_{4}\right.$ or $\mathrm{C}_{3} \mathrm{H}_{8}$ ), followed by a series of reactions to reduce the $\mathrm{CO}$ concentration. Thus, CO-tolerant catalysts such as Pt-Ru alloys have been employed.

\subsection{CO-tolerant HOR mechanism at Pt-alloys}

It has been well-known for Pt-Ru alloys that the oxidation of $\mathrm{CO}$ molecules adsorbed on Pt sites $\left(\mathrm{CO}_{\mathrm{ad}}-\mathrm{Pt}\right)$ is facilitated by oxygencontaining species on $\mathrm{Ru}$ sites (so-called bi-functional mechanism), ${ }^{116}$ a ligand (electronic) effect, ${ }^{117}$ or both. For example, the onset-potential $E_{\text {onset }}$ for the oxidation of $\mathrm{CO}_{\mathrm{ad}}$ on bulk-Pt electrode (ca. 0.5 to $0.6 \mathrm{~V}$ ) is shifted to a less positive potential (around $0.3 \mathrm{~V}$ ) on Pt-Ru alloys at room temperature. ${ }^{5,18,24}$ The $\mathrm{CO}_{\mathrm{ad}}$ oxidation rate is enhanced further by elevating the temperature or employing an oxide support (e.g., $0.21 \mathrm{~V}$ on $\mathrm{Pt}_{2} \mathrm{Ru}_{3} / \mathrm{Sb}-\mathrm{SnO}_{2}$ at $70^{\circ} \mathrm{C}$ ). ${ }^{21}$ On the other hand, we found that Pt skin/Pt-M alloys $(\mathrm{M}=\mathrm{Fe}, \mathrm{Co}, \mathrm{Ni}$, etc.) exhibited moderate $\mathrm{CO}$-tolerant $\mathrm{HOR}$ activities at temperatures $\leq$ $70^{\circ} \mathrm{C} .1,32,35$ It has been clarified by a series of experiments that excellent CO-tolerance on various alloy (including Pt-Ru) catalysts at practical potentials $E<0.1 \mathrm{~V}$ for residential PEFCs is not ascribable to the increase in the oxidation activity of $\mathrm{CO}_{\mathrm{ad}}$, because $\mathrm{CO}_{\mathrm{ad}}$ cannot be oxidized at such potentials. ${ }^{32,35,36}$

By using EC-XPS technique, we have demonstrated, for the first time, clear and direct evidence for the modified electronic structure of surface Pt atoms of Pt skin/Pt-Co and Pt-Ru, i.e., positive corelevel shift $(C L$-shift $)$ of $\mathrm{Pt}_{4 \mathrm{f}_{7 / 2}} \cdot{ }^{2,5}$ Changes in surface $C L$-shifts ( $\triangle S C L S \mathrm{~s}$ ) induced by $\mathrm{CO}_{\mathrm{ad}}$ were related to $\mathrm{CO}$ adsorption energy $E_{\text {ads }}(\mathrm{CO})$. The relationship between the $C L$-shifts and $E_{\text {ads }}(\mathrm{CO})$ was found to be linear so that the $\mathrm{CO}$ adsorption becomes weaker in the order pure $\mathrm{Pt}>\mathrm{Pt}$ skin/Pt-Co $>\mathrm{Pt}-\mathrm{Ru}$, as shown in Fig. 4. Hence, the CO-tolerant HOR activity at Pt skin/Pt-Co or Pt-Ru at $E<0.1 \mathrm{~V}$ can be ascribed to weaker $\mathrm{CO}$ adsorption, due to the modified electronic structures of the Pt surface.

\subsection{Effect of particle size and composition on CO-tolerance at Pt-alloy nanocatalysts}

For the cost reduction of residential PEFCs, it is essential to increase the $M A$ for the HOR of the anode catalysts in the presence of $\mathrm{CO}$ at higher concentrations. In order to find clear strategies for the design of highly CO-tolerant catalysts, we have examined the effect of particle size and composition on the $M A$ in the presence of $\mathrm{CO}_{\mathrm{ad}}$ and analyzed the mechanism by in situ attenuated total reflection FTIR spectroscopy (ATR-FTIR) for monodisperse n$\mathrm{Pt}_{2} \mathrm{Ru}_{3} / \mathrm{CB}$ catalysts with uniform composition prepared by the nanocapsule method. ${ }^{17,19}$

It was found that the CO-tolerance at $n-\mathrm{Pt}_{2} \mathrm{Ru}_{3} / \mathrm{CB}$ was greatly improved by a heat treatment in $5 \% \mathrm{H}_{2}$ at $200^{\circ} \mathrm{C}$ and was superior to that of a commercial c- $\mathrm{Pt}_{2} \mathrm{Ru}_{3} / \mathrm{CB}$ catalyst at an apparent coverage of $\mathrm{CO}\left(\theta_{\mathrm{CO}}\right)$ of $0.95 .{ }^{17}$ Figures $5(\mathrm{a})$, (b), and (c) shows in situ FTIR

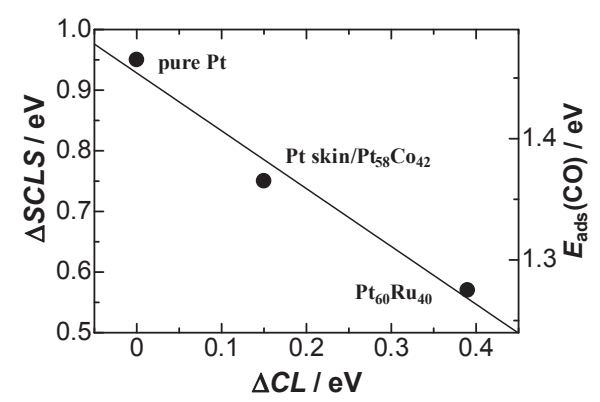

Figure 4. Linear relation between core-level shifts $(\triangle C L)$ and surface core-level shifts $\triangle S C L S S$ (CO adsorption energies, $\left.E_{\text {ads }}(\mathrm{CO})\right)$. Reproduced from Ref. 5 with permission of the American Chemical Society.
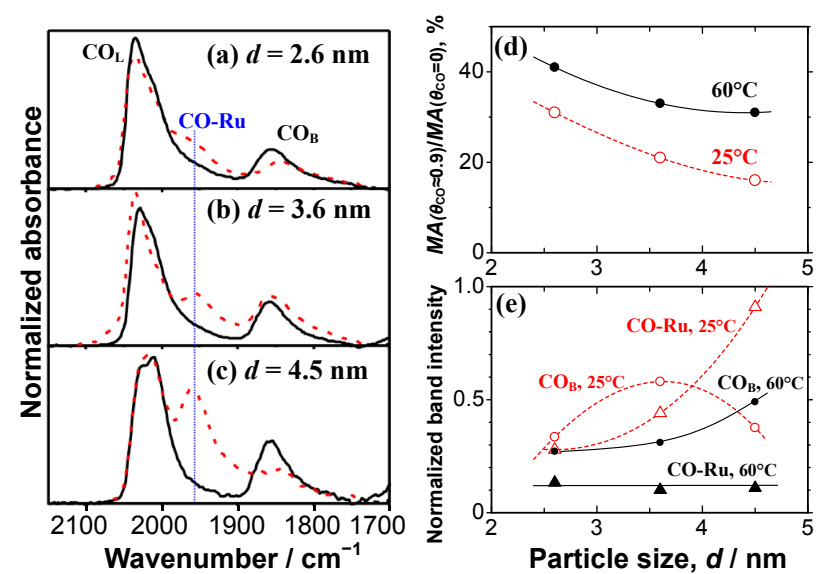

Figure 5. (Color online) Changes in FTIR spectra of Nafioncoated $\mathrm{Pt}_{2} \mathrm{Ru}_{3} / \mathrm{C}$ electrodes observed at $0.02 \mathrm{~V}$ in $1 \% \mathrm{CO}\left(\mathrm{H}_{2}\right.$ balance)-saturated $0.1 \mathrm{M} \mathrm{HClO}_{4}$ solution at $25^{\circ} \mathrm{C}$ (dashed line) and $60^{\circ} \mathrm{C}$ (solid line) after $t_{\mathrm{ad}}=120 \mathrm{~min}$ of $\mathrm{CO}$ adsorption. The spectra were normalized with respect to the value of $I\left[\mathrm{CO}_{\mathrm{L}}\right]$; (a) $d=2.6 \mathrm{~nm}$, (b) $3.6 \mathrm{~nm}$, and (c) $4.5 \mathrm{~nm}$. Panels (d) and (e) show the particle size dependencies of CO-tolerance parameter $M A\left(\theta_{\mathrm{CO}} \approx 0.9\right) / M A\left(\theta_{\mathrm{CO}}=\right.$ $0)$ and band intensities of $(\mathrm{O}, \boldsymbol{\bullet}) \mathrm{I}\left[\mathrm{CO}_{\mathrm{B}}\right]$ and $(\triangle, \boldsymbol{\Delta}) I[\mathrm{CO}-\mathrm{Ru}]$ at $25^{\circ} \mathrm{C}$ (dashed line) and $60^{\circ} \mathrm{C}$ (solid line) after $t_{\text {ad }}=120 \mathrm{~min}$. Reproduced from Ref. 19 with permission of the American Chemical Society.

spectra of $\mathrm{CO}_{\mathrm{ad}}$ on $\mathrm{n}-\mathrm{Pt}_{2} \mathrm{Ru}_{3} / \mathrm{CB}$ with $d=2.6,3.6$, and $4.5 \mathrm{~nm}$ after $\mathrm{CO}$ adsorption. Since the $\theta_{\mathrm{CO}}$ values became nearly constant at ca. 0.9 for all catalysts at 25 and $60^{\circ} \mathrm{C}$, the values of $M A\left(\theta_{\mathrm{CO}} \approx 0.9\right) /$ $M A\left(\theta_{\mathrm{CO}}=0\right)$ were calculated as a measure of CO-tolerance and plotted as a function of $d$ in Fig. 5(d). The CO-tolerance increased with decreasing particle size at 25 and $60^{\circ} \mathrm{C}$. The integrated intensities of three bands (linearly adsorbed on $\mathrm{Pt}, \mathrm{CO}_{\mathrm{L}}$; bridged on Pt-Pt pair sites, $\mathrm{CO}_{\mathrm{B}} ; \mathrm{CO}_{\mathrm{B}}$ on $\mathrm{Ru}-\mathrm{Ru}$ and $\mathrm{Ru}-\mathrm{Pt}$ sites, $\mathrm{CO}-\mathrm{Ru}$ ) changed with temperature and particle size $d$, as shown in Fig. 5(e). At $25^{\circ} \mathrm{C}$, the suppression of $\mathrm{CO}-\mathrm{Ru}$ was a dominant factor to maintain the electronic modification effect that decreases the $E_{\text {ads }}(\mathrm{CO})$. Based on the hydrogen adsorption charge for the COfree surface in the cyclic voltammograms, it was found that the atomic ratio of $\mathrm{Pt} / \mathrm{Ru}$ on the top surface increased with decreasing $d$ : a Pt-rich top-surface and a Ru-rich core was essential for high COtolerance at $25^{\circ} \mathrm{C}$. In contrast, at $60^{\circ} \mathrm{C}$, the coverage of $\mathrm{CO}_{\mathrm{B}}$ on $\mathrm{Pt}$ sites was the lowest on the smallest $\mathrm{Pt}_{2} \mathrm{Ru}_{3}$ particles. Because $\mathrm{CO}_{\mathrm{B}}$ blocks two active sites for the HOR, the largest number of HOR active sites can be available at the smallest particle. It was also found at $60^{\circ} \mathrm{C}$ that $\mathrm{n}-\mathrm{Pt}_{2} \mathrm{Ru}_{3} / \mathrm{CB}$ exhibited higher $\mathrm{CO}$-tolerance than that at $\mathrm{n}-\mathrm{PtRu} / \mathrm{CB}$ (50 atom\%-Ru) with the identical $d=2.6 \mathrm{~nm}$, probably due to the Ru-rich core that modifies the electronic structure of the Pt surface. ${ }^{19}$

Very recently, we have developed novel anode catalysts $\mathrm{Pt}_{x \mathrm{AL}}-\mathrm{Pt}-$ $\mathrm{M} / \mathrm{C}(\mathrm{M}=\mathrm{Fe}, \mathrm{Co}, \mathrm{Ni})$, which were originally synthesized for the cathode catalysts (see Sect. 2.3) supported on high-surface area carbon. They showed superlative CO-tolerance and high robustness with respect to air exposure at 70 to $90^{\circ} \mathrm{C} .{ }^{54,55} \mathrm{The}^{\mathrm{Pt}} t_{x \mathrm{AL}}-\mathrm{PtFe} / \mathrm{C}$ catalyst exhibited the highest CO-tolerant HOR activity $\left(j_{\mathrm{s}}\right.$ and $\left.M A\right)$, followed by $\mathrm{Pt}_{x \mathrm{AL}}-\mathrm{PtCo} / \mathrm{C}$ and $\mathrm{Pt}_{x \mathrm{AL}}-\mathrm{PtNi} / \mathrm{C}$. In situ ATR-FTIR, ${ }^{22}$ in situ X-ray absorption spectroscopy, ${ }^{118}$ and DFT calculations ${ }^{55}$ clearly demonstrated the weakening of $\mathrm{CO}$ adsorption on the $\mathrm{Pt}_{x \mathrm{AL}}$.

\subsection{Anode catalysts for direct oxidation fuel cells}

Direct oxidation fuel cells (DOFCs) have the unique advantages of a simple system and ease of maintenance, which are suitable for the application to portable electronic devices, wheelchairs, vehicles, and robots. Aqueous solutions of methanol, formaldehyde, formic 
acid, and methoxy compounds are directly fed to the anode and electrochemically oxidized. We have investigated the methanol oxidation reaction (MOR) and the $\mathrm{CO}_{\mathrm{ad}}$ oxidation at various catalysts. ${ }^{119-123}$ The $E_{\text {onset }}$ for the MOR was found to coincide well with that for the $\mathrm{CO}_{\mathrm{ad}}$ oxidation reaction $\left(\mathrm{CO}_{\mathrm{ad}} \mathrm{OR}\right)$ at $\mathrm{Pt}$ and Pt-Ru alloys, ${ }^{121,122}$ because $\mathrm{CO}_{\mathrm{ad}}$ is the intermediate in the MOR, with a facile dehydrogenation reaction. Among various catalysts examined in acidic media, $\mathrm{Pt}-\mathrm{Ru}$ alloys have exhibited the highest activity for the MOR or $\mathrm{CO}_{\mathrm{ad}} \mathrm{OR}$ from 20 to $120^{\circ} \mathrm{C} .{ }^{120,123} \mathrm{By}$ in situ ATR-FTIR for $\mathrm{CO}$-adsorbed $\mathrm{Pt} / \mathrm{CB}, \mathrm{Pt}_{3} \mathrm{Co} / \mathrm{CB}$, and $\mathrm{PtRu} / \mathrm{CB}$ from 23 to $60^{\circ} \mathrm{C}$, a sharp band around $3630 \mathrm{~cm}^{-1}$ was observed, which was assigned to $v(\mathrm{OH})$ of non-hydrogen bonded, isolated water (co-adsorbed with $\mathrm{CO}){ }^{13,18,121}$ Changes in the $v(\mathrm{OH})$ during the $\mathrm{CO}_{\mathrm{ad}} \mathrm{OR}$ clearly indicated that the dominant factor for determining the oxidation activity was the $E_{\text {onset }}$ for the oxidation of the isolated water to provide an oxygen species (Pt-OH or $\mathrm{Ru}-\mathrm{OH})$. The values of $E_{\text {onset }}\left(\mathrm{H}_{2} \mathrm{O}\right)$ at $\mathrm{PtRu} / \mathrm{CB}$ were lowest among the three catalysts. Furthermore, the $\mathrm{CO}_{\mathrm{ad}} \mathrm{OR}$ rate at $\mathrm{PtRu} / \mathrm{CB}$ was facilitated by both the bi-functional mechanism and the weakened $\mathrm{CO}$ adsorption due to the modification of the Pt electronic structure. The $E_{\text {onset }}\left(\mathrm{H}_{2} \mathrm{O}\right)$ values shifted to less positive potentials with increasing temperature, resulting in an increase in the $\mathrm{CO}_{\mathrm{ad}} \mathrm{OR}$ activity, specifically at $\mathrm{Pt} / \mathrm{CB}$ and $\mathrm{Pt}_{3} \mathrm{Co} / \mathrm{CB} .{ }^{18}$

We also examined the electrooxidation of poly-oxymethylenedimethylethers $\left(\mathrm{CH}_{3}-\mathrm{O}-\left(\mathrm{CH}_{2}-\mathrm{O}\right)_{\mathrm{n}}-\mathrm{CH}_{3}, \mathrm{POMMs}\right)$, which are alternative liquid fuels with lower toxicity and lower vapor pressure compared with methanol. ${ }^{50,124}$ The POMMs are hydrolyzed easily in acidic media to provide methanol and formaldehyde. While PtRu/ $\mathrm{CB}$ was the active catalyst for the oxidation of hydrolyzed POMM, the activity was enhanced greatly by the use of an $\mathrm{Sb}-\mathrm{SnO}_{2}$ support $\left(\mathrm{PtRu} / \mathrm{Sb}-\mathrm{SnO}_{2}\right)$, probably due to an electronic modification effect. ${ }^{50}$

\section{Design of Catalyst Layers with High Effectiveness of Pt}

As described above, in addition to the R\&D of highly active, highly durable catalysts, it is very important to establish the strategies for the design of catalyst layer (CL) structures with increased utilization (effectiveness) ${ }^{125}$ of Pt-based NPs. In a typical CL, Pt/CB or Pt-M alloy/CB catalysts are coated with the electrolyte binder (ionomer, typically, perfluorinated sulfonic acid (PFSA) polymers such as Nafion), which acts as the proton-conducting network. The proton conductance $\sigma_{\mathrm{H}}$ increases with increasing binder thickness coated on the Pt-based NPs, but, in turn, the $\mathrm{O}_{2}$ gas diffusion rate decreases. We developed a novel preparation procedure of Nafioncoated $\mathrm{Pt} / \mathrm{CB}$ for the $\mathrm{CL}$ with high Pt effectiveness. ${ }^{60}$ Very uniform distribution of the binder in the CL was demonstrated, for the first time, by an electron tomography (3D-TEM). ${ }^{61}$ However, we still need to improve the CL performance further under widely ranging operating conditions of relative humidity (RHs) and temperature.

\section{1 $\mathrm{SiO}_{2}$-containing catalyst layers for low humidity operation}

It is effective for cost reduction to avoid the use of an external humidifier for $\mathrm{H}_{2}$-fuel gas and/or air and to operate at low $\mathrm{RH}$. However, the $\sigma_{H}$ values in both the PEM and the binder decrease at low $\mathrm{RH}$, resulting in increases in both ohmic loss and overpotential. In order to increase the effectiveness of Pt NPs at low RH, we prepared CLs containing hygroscopic $\mathrm{SiO}_{2} \mathrm{NPs}\left(\mathrm{SiO}_{2}-\mathrm{CLs}\right){ }^{69,70}$ The cell performance at low RHs was improved with increasing $\mathrm{SiO}_{2}$ content (volume ratio of $\mathrm{SiO}_{2}$ to carbon, $V_{\mathrm{SiO} 2} / V_{\mathrm{C}}$ ). The ohmic resistances of the cell $R_{\text {cell }}$ decreased with increasing $V_{\mathrm{SiO} 2} / V_{\mathrm{C}}$, indicating an increase in water content. However, the $I-E$ performance gain was much larger than that expected for the reduction of ohmic loss. For the $\mathrm{SiO}_{2}-\mathrm{CL}$ with $V_{\mathrm{SiO} 2} / V_{\mathrm{C}}=0.39$ at $80^{\circ} \mathrm{C}$ and $30 \%$ $\mathrm{RH}$, the value of $M A_{0.85 \mathrm{~V}}$ was 2.6 times larger than that without $\mathrm{SiO}_{2}$, as shown in Fig. 6(a). The cyclic voltammograms of the $\mathrm{SiO}_{2}$-CLs (Fig. 6(b)) clearly indicated that the effectiveness of the Pt cathode
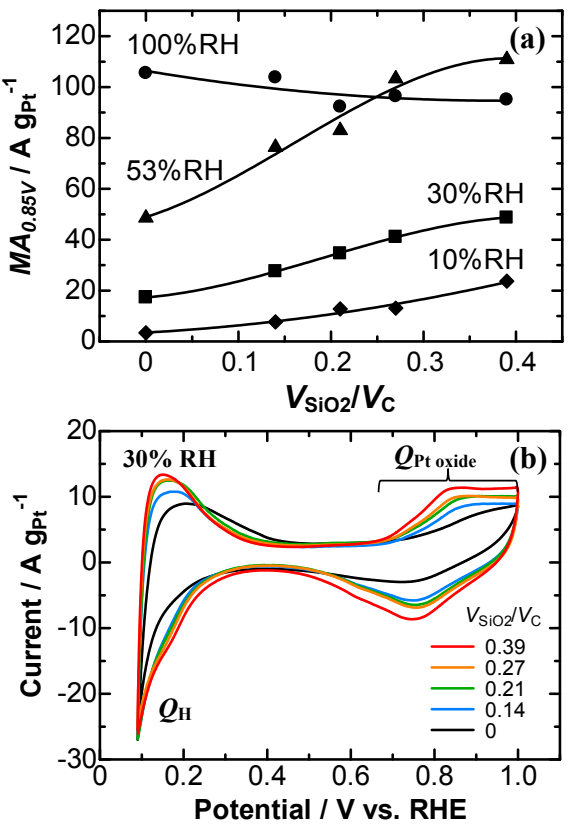

Figure 6. (Color online) Effect of $\mathrm{SiO}_{2}$ addition in the CLs on (a) mass activity at $0.85 \mathrm{~V}\left(M A_{0.85 \mathrm{~V}}\right)$ obtained from polarization curves at $80^{\circ} \mathrm{C}$ for $\mathrm{H}_{2} / /$ air fuel cell under various RHs and (b) cyclic voltammograms of CLs measured at $80^{\circ} \mathrm{C}$ in $\mathrm{N}_{2}$ with $30 \% \mathrm{RH}$ at the sweep rate of $20 \mathrm{mV} \mathrm{s}^{-1}$. The loading amount of Pt in the CLs was $0.56 \pm 0.02 \mathrm{mg} \mathrm{cm}^{-2}$. While the volume ratio of dry Nafion to carbon black support and $\mathrm{SiO}_{2}, V_{\mathrm{Nafion}} /\left(V_{\mathrm{C}}+V_{\mathrm{SiO} 2}\right)$, was maintained constant at 0.77 , in order to obtain a constant thickness of Nafion binder on the Pt catalyst particles, the volume ratio of $\mathrm{SiO}_{2}$ to carbon $\left(V_{\mathrm{SiO} 2} / V_{\mathrm{C}}\right)$ was changed from 0 (without $\left.\mathrm{SiO}_{2}\right)$ to 0.39 . Identical CLs were used for the anode and the cathode. Reproduced from Ref. 70 with permission of Elsevier Ltd.

catalyst increased, not only due to the increased electrochemically active area ( $E C A$, based on hydrogen adsorption charge, $\left.Q_{\mathrm{H}}\right)$ resulting from a good proton-conducting network, but also to the suppression of the specific adsorption of the sulfonate anions in the electrolyte binder on the Pt surface (increase in $Q_{\mathrm{Pt} \text { oxide), which is }}$ often a serious problem of low RH operation. It was also found that the use of an $\mathrm{SiO}_{2}$-containing anode $\mathrm{CL}$ promoted the back-diffusion of water from the cathode to the anode, leading to an increase in the water content in the PEM (the reason for the lower ohmic drop), as well as increasing the oxygen partial pressure in the cathode CL (by suppressing the counter-flow of generated water vapor). ${ }^{70}$

\subsection{Cathode catalyst layers with sulfonated hydrocarbon electrolyte binders}

PFSA polymers such as Nafion have been widely used as both the PEM and the binder because of their high $\sigma_{H}$ as well as chemical and thermal stability. Recently, non-fluorinated hydrocarbon (HC) electrolyte membranes have been developed to reduce cost, to elevate the operating temperature, and to avoid environmental pollution due to fluoride on disposal. Specifically, the elevation of operating temperature $\left(\geq 100^{\circ} \mathrm{C}\right)$ leads to a significant cost reduction by increases in the $M A$ values for the $\mathrm{ORR}^{40}$ of the cathode catalysts and the CO-tolerant HOR of the anode catalysts, ${ }^{36,55}$ together with a down-sizing of the heat exchanger (radiator) in FCVs (due to increased $\Delta T$ ).

The $\sigma_{\mathrm{H}}$ values in $\mathrm{HC}$ electrolytes so far are high enough at high $\mathrm{RH}$ but decrease more steeply with decreasing RH than that in the case of Nafion. In contrast, sulfonated poly(arylene ether) ionomers containing sulfofluorenyl groups (SPAE, as shown in Fig. 7(a)), which were prepared by Miyatake and coworkers in our laboratory, 
(a)
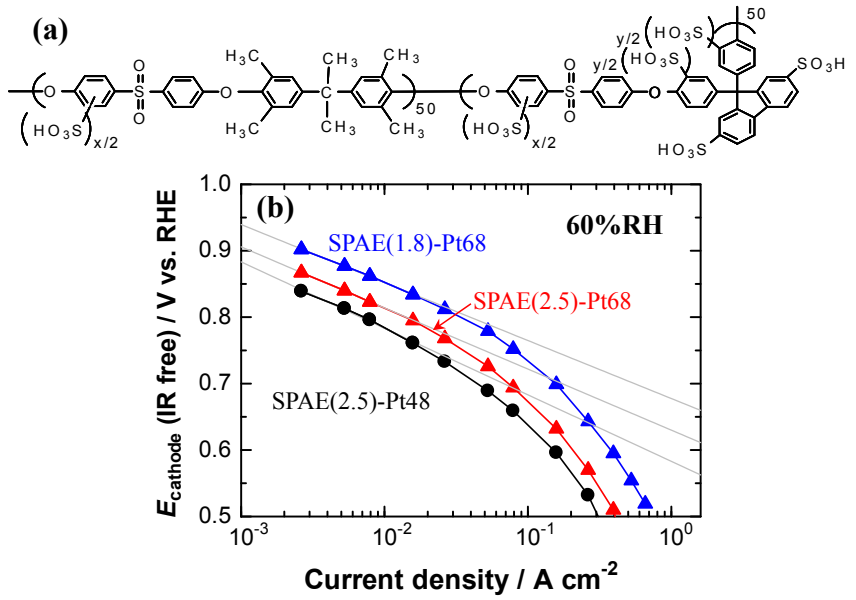

Figure 7. (Color online) (a) Chemical structure of the sulfonated poly(arylene ether) (SPAE) ionomer, (b) steady-state cathode polarization curves in air for the CLs of SPAE(1.8)-Pt68 ( $\mathbf{\Delta}$ ),

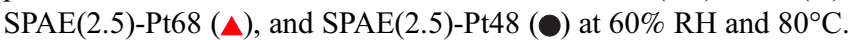
$\operatorname{SPAE}(1.8)$ and $\operatorname{SPAE}(2.5)$ mean the SPAE binder with the ion exchange capacity of 1.8 and $2.5 \mathrm{meq}^{-1}$, respectively. Commercial $\mathrm{Pt} / \mathrm{CB}$ catalyst with Pt-loadings of either $48 \mathrm{wt} \%$ (Pt48) or $68 \mathrm{wt} \%$ (Pt68) was used. The mass ratio of SPAE binder (dry basis) to carbon black (SPAE/C) was adjusted to 0.70. NRE212 was used as the electrolyte membrane in the fuel cell with $\mathrm{H}_{2}$ and air $\left(200 \mathrm{~mL} \mathrm{~min}^{-1}\right)$ under ambient pressure. Reproduced from Ref. 66 with permission of Elsevier Ltd.

showed $\sigma_{\mathrm{H}}$ values comparable to that of Nafion at $\mathrm{RH} \geq 58 \%$ and $80^{\circ} \mathrm{C} .{ }^{126}$ The performances of the cathode CLs containing SPAE binder (SPAE-CL) were examined from 60 to $100 \% \mathrm{RH}$ at $80^{\circ} \mathrm{C} .{ }^{65,66}$ The values of $M A$ at $0.9 \mathrm{~V}$ (measure of the catalyst utilization) in air and $\mathrm{O}_{2}$ at the SPAE-CL reached a maximum at $88 \%$ RH and decreased steeply below $78 \%$ RH. By a series of experiments, the decrease in the performance at the SPAE-CL was ascribed to a decrease in the $\mathrm{O}_{2}$-diffusion rate by excessive swelling of SPAE at high RH and a specific adsorption of functional groups (probably sulfonate groups) in the SPAE on the Pt catalyst surface at low RH. Then, the SPAE-CL performance was successfully improved over the whole range of current densities by using a high Pt-loading for the $\mathrm{Pt} / \mathrm{CB}$ catalyst $(68 \mathrm{wt} \%-\mathrm{Pt})$ in place of the conventional $48 \mathrm{wt} \%$-Pt for the reduction of CL thickness, which enabled us to increase the $\mathrm{O}_{2}$-diffusion rate and to suppress the adsorption of SPAE binder on the Pt surface (via effective utilization of generated water within a thin CL). As shown in Fig. 7(b), the performance at low RH $(60 \% \mathrm{RH})$ was improved further by employing an SPAE binder with a lower ion exchange capacity (IEC) of $1.8 \mathrm{meq}^{-1}$ [SPAE(1.8)] to suppress the specific adsorption of SPAE, in place of that with IEC $=2.5[\operatorname{SPAE}(2.5)]$. Hence, for the SPAE-CLs, the use of a high Pt-loading catalyst, together with a binder with an appropriate IEC, is very important. ${ }^{66}$

\section{High Performance and Durable Electrodes for Reversible Solid Oxide Cell (R-SOC)}

The R-SOC acts as an efficient, reciprocal direct energy converter between hydrogen and electricity. ${ }^{127-129}$ Large-scale amounts of electricity generated from photovoltaics or wind power can be stored as $\mathrm{H}_{2}$ gas when the SOC is operated as an SOEC, while electric power is generated by the reverse operation mode (SOFC) to match the supply with demand. The high operating temperature of the RSOC indeed provides the great advantage of reduced overvoltage without the use of noble-metal electrocatalysts, but its disadvantage is the rapid degradation of materials. Thus, a reduced temperature operation $\left(600-800^{\circ} \mathrm{C}\right)$ is a good option to decrease not only the degradation rates but also costs of materials and their manufacturing.

We have engaged in the R \& D of high-performance electrodes with novel architecture for reduced temperature SOFCs since the 1990 's, ${ }^{78,79}$ when such research was quite rare, but it has become more common nowadays. In order to enlarge the effective reaction zone (ERZ, in which gases, ions, and electrons are transported smoothly), we proposed a new concept of catalyzed reaction layers. ${ }^{79}$ Mixed ionic and electronic conducting samaria-doped ceria $\left(\mathrm{CeO}_{2}\right)_{0.8}\left(\mathrm{SmO}_{1.5}\right)_{0.2}$ (denoted as $\mathrm{SDC}$ ) with highly dispersed metal electrocatalysts exhibited very high performance as the hydrogen electrode at reduced temperatures. It was found that the $\mathrm{Ni}$ or $\mathrm{Ni}-\mathrm{Co}$ NPs played a highly active role in the hydrogen oxidation/evolution reactions. ${ }^{91-95,98}$ The activity of the hydrogen electrode in the SOEC was found to increase with an increase in the ionic conductivity $\sigma_{\text {ion }}$ of the zirconia electrolyte, ${ }^{95}$ similar to the case of SOFC electrodes: ${ }^{78,81,84,86}$ the use of high-performance electrodes in combination with the a solid electrolyte having high $\sigma_{\text {ion }}$ is essential to achieve high performance R-SOCs.

Very recently, we have developed double-layer (DL) hydrogen electrodes, consisting of an SDC scaffold with highly dispersed $\mathrm{Ni}$ or $\mathrm{Ni}_{0.9} \mathrm{Co}_{0.1} \mathrm{NPs}$ as the catalyst layer and a thin Ni-SDC current collecting layer, as shown in Fig. 8. The DL $\mathrm{H}_{2}$ electrode exhibited highly reversible performance in both anodic and cathodic operation modes at $800^{\circ} \mathrm{C} \cdot{ }^{130,131}$ For the oxygen electrodes, a composite of $\mathrm{La}_{0.6} \mathrm{Sr}_{0.4} \mathrm{Co}_{0.2} \mathrm{Fe}_{0.8} \mathrm{O}_{3}$ (LSCF) and SDC with SDC interlayer, in which SDC acted as a high oxide ionic conductor in oxygen atmosphere, exhibited very reversible performance and high durability. ${ }^{96,99,100}$ An IR-free electrolytic cell potential $E_{\text {cell }}$ of $1.21 \mathrm{~V}$ for a full cell with the configuration of DL $\mathrm{H}_{2}$ electrode | YSZ electrolyte $\mid$ SDC interlayer $\mid$ LSCF-SDC $\mathrm{O}_{2}$ electrode was achieved at $j=-0.5 \mathrm{~A} \mathrm{~cm}^{-2}$ and $800^{\circ} \mathrm{C}$ with $p\left[\mathrm{H}_{2} \mathrm{O}\right]=0.4 \mathrm{~atm}$ (cathode) and pure $\mathrm{O}_{2}$ (anode). If we add the ohmic loss of the scandia-stabilized zirconia electrolyte with a thickness of $50 \mu \mathrm{m},{ }^{132}$ the $E_{\text {cell }}$ value is calculated to be $1.23 \mathrm{~V}$, which is quite superior to that reported for an electrolyte-supported cell. ${ }^{133}$ Durability tests of the full cell, as well as the fabrication of a large test cell, are in progress.

\section{Conclusions and Outlook}

Based on the analyses of fuel cell reactions by multilateral techniques, clear strategies for the design of electrocatalysts with high activity and high durability have been demonstrated. A key factor for high durability with high $M A$ for the ORR was found to be the uniformity in the size $\left(\sigma_{\mathrm{d}} \leq 10 \%\right)$ and high dispersion state of Pt on the support, so that we can avoid any adverse "particle-size effects." The ORR activity was improved noticeably by alloying with transition metals $(\mathrm{Fe}, \mathrm{Co}$, and $\mathrm{Ni}$ ), where the surfaces consist of a Pt skin with modified electronic structure. The increase in $\theta\left[\mathrm{O}_{\mathrm{ad}}\right]$ at the Pt skin was clearly demonstrated by EC-XPS and EQCM measurements, contrary to the common view of simple suppression of "OH poisoning." We have clarified for $\mathrm{Pt}_{x \mathrm{AL}}-\mathrm{PtCo}$ that a very important factor for superior ORR activity and durability in the ADT is well-controlled formation of a stable, uniform, thin Pt skin layer, which protects the underlying alloy from corrosion and maintains the modified electronic structure. The optimization of composition and particle size of Pt-Ru anode catalysts was found to be effective in enhancing the CO-tolerance, while the $\mathrm{Pt}_{x \mathrm{AL}^{-}}$ $\mathrm{PtCo} / \mathrm{C}$ catalysts open up the possibility of developing a new class of anode catalysts with superior performance. New catalyst layers and MEAs have been developed in order to make the electrocatalysts operate effectively, specifically under low RH conditions. Several important concepts have been demonstrated for developing oxygen and hydrogen electrodes with high performance and durability for R-SOCs. 

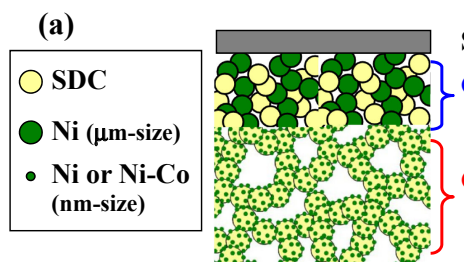

Separator (Interconnect)

Current collecting layer (CCL) Ni-YSZ cermet

Catalyst layer (CL) Ni or Ni-Co dispersed SDC

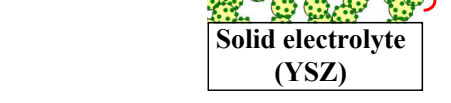

(b)
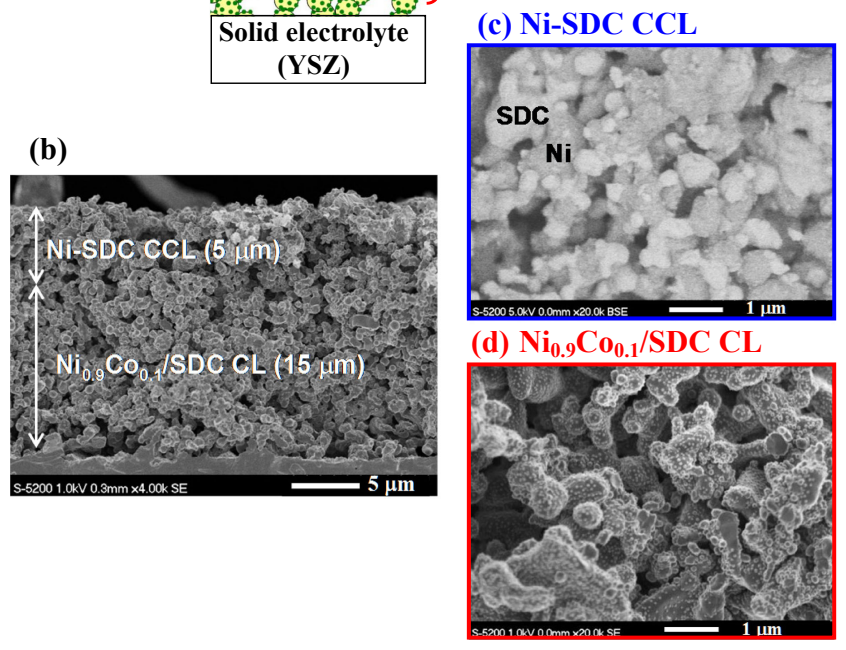

Figure 8. (Color online) (a) Schematic representation of doublelayer (DL) hydrogen electrode composed of highly-dispersed $\mathrm{Ni}$ or $\mathrm{NiCo} / \mathrm{SDC}$ as a catalyst layer (CL) and Ni-SDC cermet as a current collecting layer (CCL), (b) cross-sectional SEM images of DL hydrogen electrodes (low magnification), (c) high magnification BSE (back-scattered electron) image of Ni-SDC (60 vol\% Ni) CCL, and (d) high magnification SEM image of $\mathrm{Ni}_{0.9} \mathrm{Co}_{0.1} / \mathrm{SDC}(8 \mathrm{vol} \%$ $\left.\mathrm{Ni}_{0.9} \mathrm{Co}_{0.1}\right) \mathrm{CL}$.

For the results described above, research efforts ranging from fundamentals to applications are seen to be very important. In our group, various researchers and students work together on the preparation and evaluation of electrocatalysts, PEMs, MEAs, and their multilateral analyses (mechanisms of operation and degradation). Rapid feedback of the information can greatly accelerate the PDCA (Deming) cycles for developing materials and analysis techniques. We are hopeful that our efforts might contribute to the development of fuel cells with high performance and high durability in the near future.

\section{Acknowledgment}

The present work has been performed mainly at the University of Yamanashi, together with many collaborators in various universities, institutes, and companies. The author would like to cordially thank the supervisors, students, postdoctoral fellows, colleagues, and collaborators. The work on PEFCs was supported by funds for a "Leading Project" of the Ministry of Education, Science, Culture, Sports and Technology (MEXT) of Japan, the "Research on Nanotechnology for High Performance Fuel Cells (HiPer-FC)" Project, the "Highly CO-Tolerant Anode Catalysts for Residential PEFCs Project," and the "Superlative, Stable, and Scalable Performance Fuel Cell (SPer-FC)" Project from the New Energy and Industrial Technology Development Organization (NEDO) of Japan. The work on the SOFC/SOEC was supported by a Grant-in-Aid for Scientific Research on a Priority Area "Nanoionics" (No. 19017008) and Scientific Research B (No. 15360365, No. 17360335, and No. 21350114), the City Area Program (Yamanashi Kuninaka Area) from MEXT, and funds for the Advanced Low Carbon Technology Research and Development Program (ALCA) from the Japan Science and Technology Agency (JST).

\section{References}

1. M. Watanabe and H. Uchida, Fuel Cell Catalysis: A Surface Science Approach (Ed. M. T. M. Koper), John Wiley and Sons, New Jersey, p. 317 (2009).

2. M. Wakisaka, M. Watanabe, and H. Uchida, Fuel Cell Science: Theory, Fundamentals, and Biocatalysis (Eds. A. Wieckowski and J. K. Nørskov), John Wiley and Sons, New Jersey, p. 147 (2010).

3. H. Uchida, H. Yano, M. Wakisaka, and M. Watanabe, Electrochemistry, 79, 303 (2011).

4. M. Watanabe, D. A. Tryk, M. Wakisaka, H. Yano, and H. Uchida, Electrochim. Acta, 84, 187 (2012).

5. M. Wakisaka, S. Mitsui, Y. Hirose, K. Kawashima, H. Uchida, and M. Watanabe, J. Phys. Chem. B, 110, 23489 (2006).

6. M. Wakisaka, H. Suzuki, S. Mitsui, H. Uchida, and M. Watanabe, J. Phys. Chem. C, 112, 2750 (2008).

7. M. Wakisaka, H. Suzuki, S. Mitsui, H. Uchida, and M. Watanabe, Langmuir, 25, 1897 (2009).

8. M. Wakisaka, Y. Udagawa, H. Suzuki, H. Uchida, and M. Watanabe, Energy Environ. Sci., 4, 1662 (2011).

9. K. Kunimatsu, H. Uchida, M. Osawa, and M. Watanabe, J. Electroanal. Chem., 587, 299 (2006).

10. T. Sato, K. Kunimatsu, H. Uchida, and M. Watanabe, Electrochim. Acta, 53, 1265 (2007).

11. K. Kunimatsu, T. Sato, H. Uchida, and M. Watanabe, Langmuir, 24, 3590 (2008).

12. K. Kunimatsu, T. Sato, H. Uchida, and M. Watanabe, Electrochim. Acta, 53, 6104 (2008).

13. M. Watanabe, T. Sato, K. Kunimatsu, and H. Uchida, Electrochim. Acta, 53, 6928 (2008).

14. K. Kunimatsu, H. Hanawa, H. Uchida, and M. Watanabe, J. Electroanal. Chem., 632, 109 (2009).

15. H. Hanawa, K. Kunimatsu, H. Uchida, and M. Watanabe, Electrochim. Acta, 54, 6276 (2009).

16. K. Kunimatsu, T. Yoda, D. A. Tryk, H. Uchida, and M. Watanabe, Phys. Chem. Chem. Phys., 12, 621 (2010).

17. T. Sato, K. Kunimatsu, K. Okaya, H. Yano, M. Watanabe, and H. Uchida, Energy Environ. Sci., 4, 433 (2011).

18. T. Sato, K. Kunimatsu, M. Watanabe, and H. Uchida, J. Nanosci. Nanotechnol., 11, 5123 (2011).

19. T. Sato, K. Okaya, K. Kunimatsu, H. Yano, M. Watanabe, and H. Uchida, ACS Catal., 2, 450 (2012).

20. H. Hanawa, K. Kunimatsu, M. Watanabe, and H. Uchida, J. Phys. Chem. C, 116, 21401 (2012).

21. Y. Ogihara, H. Yano, M. Watanabe, A. Iiyama, and H. Uchida, Catalysts, 6, 139 (2016).

22. Y. Ogihara, H. Yano, T. Matsumoto, D. A. Tryk, A. Iiyama, and H. Uchida, Catalysts, 7, 8 (2017).

23. H. Uchida, H. Ozuka, and M. Watanabe, Electrochim. Acta, 47, 3629 (2002).

24. I. Kanezashi, S. Nohara, J. Omura, M. Watanabe, and H. Uchida, J. Electroanal. Chem., 662, 123 (2011).

25. J. Omura, H. Yano, M. Watanabe, and H. Uchida, Langmuir, 27, 6464 (2011).

26. J. Omura, H. Yano, D. A. Tryk, M. Watanabe, and H. Uchida, Langmuir, 30, 432 (2014).

27. L.-J. Wan, T. Moriyama, M. Ito, H. Uchida, and M. Watanabe, Chem. Commun., 58 (2002).

28. M. Wakisaka, T. Ohkanda, T. Yoneyama, H. Uchida, and M. Watanabe, Chem. Commun., 2710 (2005).

29. M. Wakisaka, S. Asizawa, H. Uchida, and M. Watanabe, Phys. Chem. Chem. Phys., 12, 4184 (2010).

30. J. Inukai, D. A. Tryk, T. Abe, M. Wakisaka, H. Uchida, and M. Watanabe, J. Am. Chem. Soc., 135, 1476 (2013).

31. M. Wakisaka, T. Yoneyama, S. Ashizawa, Y. Hyuga, T. Ohkanda, H. Uchida, and M. Watanabe, Phys. Chem. Chem. Phys., 15, 11038 (2013).

32. H. Igarashi, T. Fujino, Y. Zhu, H. Uchida, and M. Watanabe, Phys. Chem. Chem. Phys., 3, 306 (2001).

33. E. Higuchi, H. Uchida, and M. Watanabe, J. Electroanal. Chem., 583, 69 (2005).

34. M. Wakisaka, S. Kobayashi, S. Morishima, Y. Hyuga, D. A. Tryk, M. Watanabe, A. Iiyama, and H. Uchida, Electrochem. Commun., 67, 47 (2016).

35. H. Uchida, K. Izumi, and M. Watanabe, J. Phys. Chem. B, 110, 21924 (2006).

36. H. Uchida, K. Izumi, K. Aoki, and M. Watanabe, Phys. Chem. Chem. Phys., 11, 1771 (2009).

37. N. Wakabayashi, M. Takeichi, M. Itagaki, H. Uchida, and M. Watanabe, J. Electroanal. Chem., 574, 339 (2005).

38. N. Wakabayashi, M. Takeichi, H. Uchida, and M. Watanabe, J. Phys. Chem. B, 109, 5836 (2005).

39. H. Yano, E. Higuchi, H. Uchida, and M. Watanabe, J. Phys. Chem. B, 110, 16544 (2006).

40. H. Yano, J. Inukai, H. Uchida, M. Watanabe, P. K. Babu, T. Kobayashi, J. H. Chung, E. Oldfield, and A. Wieckowski, Phys. Chem. Chem. Phys., 8, 4932 (2006).

41. H. Yano, T. Uematsu, J. Omura, M. Watanabe, and H. Uchida, J. Electroanal. 
Chem., 747, 91 (2015).

42. H. Yano, M. Watanabe, A. Iiyama, and H. Uchida, Nano Energy, 29, 323 (2016)

43. H. Yano, M. Kataoka, H. Yamashita, H. Uchida, and M. Watanabe, Langmuir, 23, 6438 (2007).

44. H. Yano, J.-M. Song, H. Uchida, and M. Watanabe, J. Phys. Chem. C, 112, 8372 (2008).

45. K. Okaya, H. Yano, H. Uchida, and M. Watanabe, ACS Appl. Mater. Interfaces, 2, 888 (2010).

46. H. Yano, T. Akiyama, P. Bele, H. Uchida, and M. Watanabe, Phys. Chem. Chem. Phys., 12, 3806 (2010).

47. H. Yano, T. Akiyama, H. Uchida, and M. Watanabe, Energy Environ. Sci., 3, $1511(2010)$

48. H. Yano, T. Akiyama, M. Watanabe, and H. Uchida, J. Electroanal. Chem., 688, 137 (2013).

49. K. Okaya, H. Yano, K. Kakinuma, M. Watanabe, and H. Uchida, ACS Appl. Mater. Interfaces, 4, 6982 (2012).

50. D. Devaux, H. Yano, H. Uchida, J.-L. Dubois, and M. Watanabe, Electrochim Acta, 56, 1460 (2011).

51. M. Chiwata, K. Kakinuma, M. Wakisaka, M. Uchida, S. Deki, M. Watanabe, and H. Uchida, Catalysts, 5, 966 (2015).

52. M. Watanabe, H. Yano, D. A. Tryk, and H. Uchida, J. Electrochem. Soc., 163, F455 (2016)

53. M. Chiwata, H. Yano, S. Ogawa, M. Watanabe, A. Iiyama, and H. Uchida, Electrochemistry, 84, 133 (2016).

54. G. Shi, H. Yano, D. A. Tryk, M. Watanabe, A. Iiyama, and H. Uchida, Nanoscale, 8, 13893 (2016).

55. G. Shi, H. Yano, D. A. Tryk, A. Iiyama, and H. Uchida, ACS Catal., 7, 267 (2017).

56. O. Nishikawa, K. Doyama, K. Miyatake, H. Uchida, and M. Watanabe, Electrochim. Acta, 50, 2719 (2005).

57. N. Asano, M. Aoki, S. Suzuki, K. Miyatake, H. Uchida, and M. Watanabe, J. Am. Chem. Soc., 128, 1762 (2006).

58. H. Hagihara, H. Uchida, and M. Watanabe, Electrochim. Acta, 51, 3979 (2006)

59. M. Aoki, N. Asano, K. Miyatake, H. Uchida, and M. Watanabe, J. Electrochem. Soc., 153, A1154 (2006).

60. J.-M. Song, S. Suzuki, H. Uchida, and M. Watanabe, Langmuir, 22, 6422 (2006)

61. H. Uchida, J.-M. Song, S. Suzuki, E. Nakazawa, N. Baba, and M. Watanabe, $J$. Phys. Chem. B, 110, 13319 (2006).

62. E. Higuchi, K. Okamoto, K. Miyatake, H. Uchida, and M. Watanabe, Res. Chem. Intermed., 32, 533 (2006)

63. M. Aoki, Y. Chikashige, K. Miyatake, H. Uchida, and M. Watanabe, Electrochem. Commun., 8, 1412 (2006).

64. T. Yoda, H. Uchida, and M. Watanabe, Electrochim. Acta, 52, 5997 (2007).

65. T. Yoda, T. Shimura, B. Bae, K. Miyatake, M. Uchida, H. Uchida, and M. Watanabe, Electrochim. Acta, 54, 4328 (2009).

66. T. Yoda, T. Shimura, B. Bae, K. Miyatake, M. Uchida, H. Uchida, and M. Watanabe, Electrochim. Acta, 55, 3464 (2010).

67. B. Bae, T. Yoda, K. Miyatake, H. Uchida, and M. Watanabe, Angew. Chem., Int Ed., 49, 317 (2010).

68. B. Bae, T. Yoda, K. Miyatake, M. Uchida, H. Uchida, and M. Watanabe, J. Phys. Chem. B, 114, 10481 (2010)

69. N. Inoue, M. Uchida, M. Watanabe, and H. Uchida, Electrochem. Commun., 16, 100 (2012).

70. N. Inoue, M. Uchida, M. Watanabe, and H. Uchida, Electrochim. Acta, 88, 807 (2013).

71. M. Sakamoto, S. Nohara, K. Miyatake, M. Uchida, M. Watanabe, and H. Uchida, Electrochim. Acta, 137, 213 (2014)

72. M. Sakamoto, S. Nohara, K. Miyatake, M. Uchida, M. Watanabe, and H. Uchida, Electrochemistry, 83, 150 (2015)

73. S. Takaichi, H. Uchida, and M. Watanabe, Electrochem. Commun., 9, 1975 (2007).

74. S. Takaichi, H. Uchida, and M. Watanabe, J. Electrochem. Soc., 154, B1373 (2007)

75. S. Takaichi, H. Uchida, and M. Watanabe, Electrochim. Acta, 53, 4699 (2008).

76. M. Aoki, H. Uchida, and M. Watanabe, Electrochem. Commun., 7, 1434 (2005)

77. M. Aoki, H. Uchida, and M. Watanabe, Electrochem. Commun., 8, 1509 (2006)

78. H. Uchida and M. Watanabe, Modern Aspects of Electrochemistry (Eds. R. E. White and M. E. Gamboa-Aldeco), Vol. 42, Springer, New York, p. 53 (2008).

79. M. Watanabe, H. Uchida, M. Shibata, N. Mochizuki, and K. Amikura, J. Electrochem. Soc., 141, 342 (1994).

80. M. J. Saeki, H. Uchida, and M. Watanabe, Catal. Lett., 26, 149 (1994).

81. H. Uchida, M. Yoshida, and M. Watanabe, J. Phys. Chem., 99, 3282 (1995).

82. H. Uchida, N. Mochizuki, and M. Watanabe, J. Electrochem. Soc., 143, 1700 (1996).

83. H. Uchida, A. Tsuno, and M. Watanabe, Denki Kagaku (presently Electrochemistry), 64, 686 (1996).

84. M. Watanabe, H. Uchida, and M. Yoshida, J. Electrochem. Soc., 144, 1739 (1997).

85. H. Uchida, H. Suzuki, and M. Watanabe, J. Electrochem. Soc., 145, 615 (1998).

86. H. Uchida, M. Yoshida, and M. Watanabe, J. Electrochem. Soc., 146, 1 (1999).
87. H. Uchida, T. Osuga, and M. Watanabe, J. Electrochem. Soc., 146, 1677 (1999).

88. H. Uchida, S. Arisaka, and M. Watanabe, Electrochem. Solid-State Lett., 2, 428 (1999).

89. H. Uchida, S. Arisaka, and M. Watanabe, Solid State Ionics, 135, 347 (2000).

90. H. Uchida, S. Arisaka, and M. Watanabe, J. Electrochem. Soc., 149, A13 (2002).

91. H. Uchida, S. Suzuki, and M. Watanabe, Electrochem. Solid-State Lett., 6, A174 (2003).

92. H. Uchida, N. Osada, and M. Watanabe, Electrochem. Solid-State Lett., 7, A500 (2004).

93. S. Suzuki, H. Uchida, and M. Watanabe, Electrochemistry, 73, 128 (2005).

94. S. Suzuki, H. Uchida, and M. Watanabe, Solid State Ionics, 177, 359 (2006).

95. N. Osada, H. Uchida, and M. Watanabe, J. Electrochem. Soc., 153, A816 (2006).

96. Y. Tao, H. Nishino, S. Ashidate, H. Kokubo, M. Watanabe, and H. Uchida, Electrochim. Acta, 54, 3309 (2009).

97. R. Nishida, K. Kakinuma, H. Nishino, T. Kamino, H. Yamashita, M. Watanabe, and H. Uchida, Solid State Ionics, 180, 968 (2009).

98. R. Nishida, P. Puengjinda, H. Nishino, K. Kakinuma, M. E. Brito, M. Watanabe, and H. Uchida, RSC Adv, 4, 16260 (2014)

99. K. Shimura, H. Nishino, K. Kakinuma, M. E. Brito, and H. Uchida, Electrochim. Acta, 225, 114 (2017)

100. K. Shimura, H. Nishino, K. Kakinuma, M. E. Brito, and H. Uchida, J. Ceram. Soc. Jpn., 125, 218 (2017)

101. S. Mukerjee and S. Srinivasan, J. Electroanal. Chem., 357, 201 (1993).

102. T. Toda, H. Igarashi, H. Uchida, and M. Watanabe, J. Electrochem. Soc., 146, 3750 (1999).

103. V. R. Stamenkovic, T. J. Schmidt, P. N. Ross, and N. M. Markovic, J. Phys. Chem. B, 106, 11970 (2002)

104. L. J. Bregoli, Electrochim. Acta, 23, 489 (1978)

105. M. L. Sattler and P. N. Ross, Ultramicroscopy, 20, 21 (1986).

106. H. A. Gasteiger, S. S. Kocha, B. Sompalli, and F. T. Wagner, Appl. Catal., B, 56, 9 (2005).

107. M. Watanabe and S. Motoo, J. Electroanal. Chem., 60, 259 (1975).

108. H. Uchida, N. Ikeda, and M. Watanabe, J. Electroanal. Chem., 424, 5 (1997).

109. K. Matsutani, K. Hayakawa, and T. Tada, Platin. Met. Rev., 54, 223 (2010).

110. Z. Xu, H. Zhang, H. Zhong, Q. Lu, Y. Wang, and D. Su, Appl. Catal., B, 111112, 264 (2012)

111. A. V. Virkar and Y. Zhou, J. Electrochem. Soc., 154, B540 (2007).

112. "Proposal of $R \& D$ Targets and Evaluation Methods of Performances of PEFCs", http://fccj.jp/pdf/23_01_kt.pdf.

113. C. A. Reiser, L. Bregoli, T. W. Patterson, J. S. Yi, D. Yang, M. L. Perry, and T. D. Jarvi, Electrochem. Solid-State Lett., 8, A273 (2005).

114. J. K. Nørskov, J. Rossmeisl, A. Logadottir, L. Lindqvist, J. R. Kitchin, T. Bligaard, and H. Jónsson, J. Phys. Chem. B, 108, 17886 (2004).

115. V. Stamenkovic, B. S. Mun, K. J. J. Mayrhofer, P. N. Ross, N. M. Markovic, J. Rossmeisl, J. Greeley, and J. K. Nørskov, Angew. Chem., Int. Ed., 45, 2897 (2006).

116. M. Watanabe and S. Motoo, J. Electroanal. Chem., 60, 275 (1975).

117. T. Frelink, W. Visscher, and J. A. R. W. van Veen, Surf. Sci., 335, 353 (1995).

118. G. Shi, H. Yano, M. Matsumoto, H. Tanida, M. Arao, H. Imai, J. Inukai, D. A. Tryk, A. Iiyama, and H. Uchida, 84th Annual Meeting of the Electrochemical Society of Japan, Abstr., 1D12 (Tokyo, 2017).

119. M. Watanabe and H. Uchida, Handbook of Fuel Cells-Fundamentals, Technology and Applications (Eds. W. Vielstich, H. Yokokawa, and H. A. Gasteiger), Vol. 5-6, John Wiley and Sons, New Jersey, p. 81 (2009).

120. N. Wakabayashi, H. Uchida, and M. Watanabe, Electrochem. Solid-State Lett., 5, E62 (2002).

121. T. Yajima, N. Wakabayashi, H. Uchida, and M. Watanabe, Chem. Commun., 828 (2003).

122. T. Yajima, H. Uchida, and M. Watanabe, J. Phys. Chem. B, 108, 2654 (2004).

123. H. Uchida, K. Takeuchi, N. Wakabayashi, and M. Watanabe, Electrochemistry, 75, 184 (2007).

124. S. Baranton, H. Uchida, D. A. Tryk, J. L. Dubois, and M. Watanabe, Electrochim. Acta, 108, 350 (2013).

125. M. Lee, M. Uchida, H. Yano, D. A. Tryk, H. Uchida, and M. Watanabe, Electrochim. Acta, 55, 8504 (2010)

126. K. Miyatake, Y. Chikashige, E. Higuchi, and M. Watanabe, J. Am. Chem. Soc 129, 3879 (2007)

127. S. D. Ebbesen, S. H. Jensen, A. Hauch, and M. B. Mogensen, Chem. Rev, 114, 10697 (2014).

128. C. Graves, S. D. Ebbesen, S. H. Jensen, S. B. Simonsen, and M. B. Mogensen, Nat. Mater., 14, 239 (2014).

129. K. Cheng and S. P. Jiang, J. Electrochem. Soc., 163, F3070 (2016).

130. H. Uchida, P. Puengjinda, K. Miyano, K. Shimura, H. Nishino, K. Kakinuma, M. E. Brito, and M. Watanabe, ECS Trans., 68(1), 3307 (2015).

131. P. Puengjinda, H. Nishino, K. Kakinuma, M. E. Brito, and H. Uchida, J. Electrochem. Soc., 164, F889 (2017).

132. Y. Mizutani, M. Tamura, M. Kawai, and O. Yamamoto, Solid State Ionics, 72, 271 (1994)

133. X. Zhang, J. E. O’Brien, R. C. O'Brien, J. J. Hartvigsen, G. Tao, and G. K. Housley, Int. J. Hydrogen Energy, 38, 20 (2013). 